\title{
Carbon dioxide concentration in Mediterranean greenhouses: how much lost production?
}

\author{
Cecilia Stanghellini ${ }^{1}$, Luca Incrocci ${ }^{2}$, Juan Carlos Gázquez ${ }^{3}$, Biagio Dimauro ${ }^{4}$ \\ ${ }^{1}$ Wageningen UR Greenhouse Horticulture, Bornsesteeg 65, 6708 PD Wageningen, The \\ Netherlands, E-mail: cecilia.stanghellini@wur.nl \\ ${ }^{2}$ Dipartimento di Biologia delle Piante Agrarie, University of Pisa, Viale delle Piagge 23, \\ 56124 Pisa, Italy \\ ${ }^{3}$ Estación Experimental de Cajamar Las Palmerillas, 04710 El Ejido (Almería). Spain \\ ${ }^{4}$ Assessorato Agricoltura e Foreste, Regione Siciliana, U.O.S. 36-Centro colture protette, \\ Via degli studi 20, 97013 Comiso (RG), Italy
}

Keywords: assimilation, ventilation, $\mathrm{CO}_{2}$, temperature, carbon fertilisation

\begin{abstract}
In the absence of artificial supply of carbon dioxide in the greenhouse environment, the $\mathrm{CO}_{2}$ absorbed in the process of photosynthesis must ultimately come from the external ambient through the ventilation openings. This requires that the $\mathrm{CO}_{2}$ concentration within the house must be lower than the external concentration, as there would be no flow inwards otherwise. Since potential assimilation (that is, the assimilation level that can be attained when no other factor is limiting) is heavily dependent on carbon dioxide concentration, this implies that assimilation is reduced, whatever the light level or crop welfare. The ventilation of the greenhouse implies a trade-off between ensuring inflow of carbon dioxide and maintaining an adequate temperature within the house, particularly during sunny, chilly days.

We apply a simple model, on which the Dutch "philosophy" of $\mathrm{CO}_{2}$ fertilisation is based, for estimating the potential production loss through data measured in commercial greenhouses in Almeria and Sicily. Thereafter we discuss the management options for a grower to limit losses. In particular we analyse costs, potential benefits and consequences of bringing in more carbon dioxide either through increased ventilation, at the cost of lowering temperature, or through artificial supply. We find out that, whereas the reduction in production caused by depletion is comparable to the reduction resulting from the lower temperature caused by ventilation to avoid depletion, compensating the effect of depletion is much cheaper than making up the loss by heating.
\end{abstract}

\section{INTRODUCTION}

The process of photosynthesis is at the basis of plant growth and crop production. During photosynthesis the energy contained in light is used to form carbohydrates from carbon dioxide $\left(\mathrm{CO}_{2}\right)$ taken from the air, and the water present in the leaf tissue. The speed with which carbohydrates are formed (the rate of the process) is then primarily dependent on the amount of light and $\mathrm{CO}_{2}$ concentration. Temperature and water content of the leaf tissue (turgor) play a secondary role that will not be considered in this context. The response of photosynthesis to both light and aerial concentration of $\mathrm{CO}_{2}$ is of the saturating type, that is to say that photosynthesis increases by an ever smaller rate with 
each of the two factors until a level is reached beyond which increasing further the factor has no effect any more (the law of diminishing returns). Through extensive measurements in commercial greenhouse tomato crops in the Dutch Westland, Nederhoff (1994) determined a 5-parameters model of net assimilation of a full-grown tomato crop vs $\mathrm{CO}_{2}$ concentration and light. For the purpose of this work we have selected a simpler model that does reproduce the trend and the level of the original one:

$$
A_{\text {net }}=2.2 \frac{1}{1+\frac{230}{\mathrm{CO}_{2}}}[1-\exp (-0.0010 \mathrm{I})]
$$

where $\mathrm{CO}_{2}$ is the ambient carbon dioxide concentration in vpm and $I$ is the photon flux

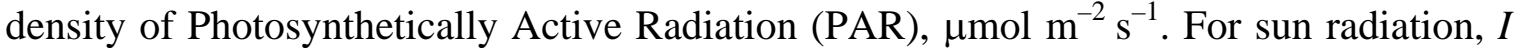
can be estimated as twice the value of sun radiation in $\mathrm{W} \mathrm{m}^{-2}$. The trend of eq(1), shown in Fig. 1, is asymptotic with respect to both radiation and $\mathrm{CO}_{2}$ but the level of the asymptote depends on the other variable, that is: each of the two factors may be limiting assimilation, whatever the value assumed by the other one.

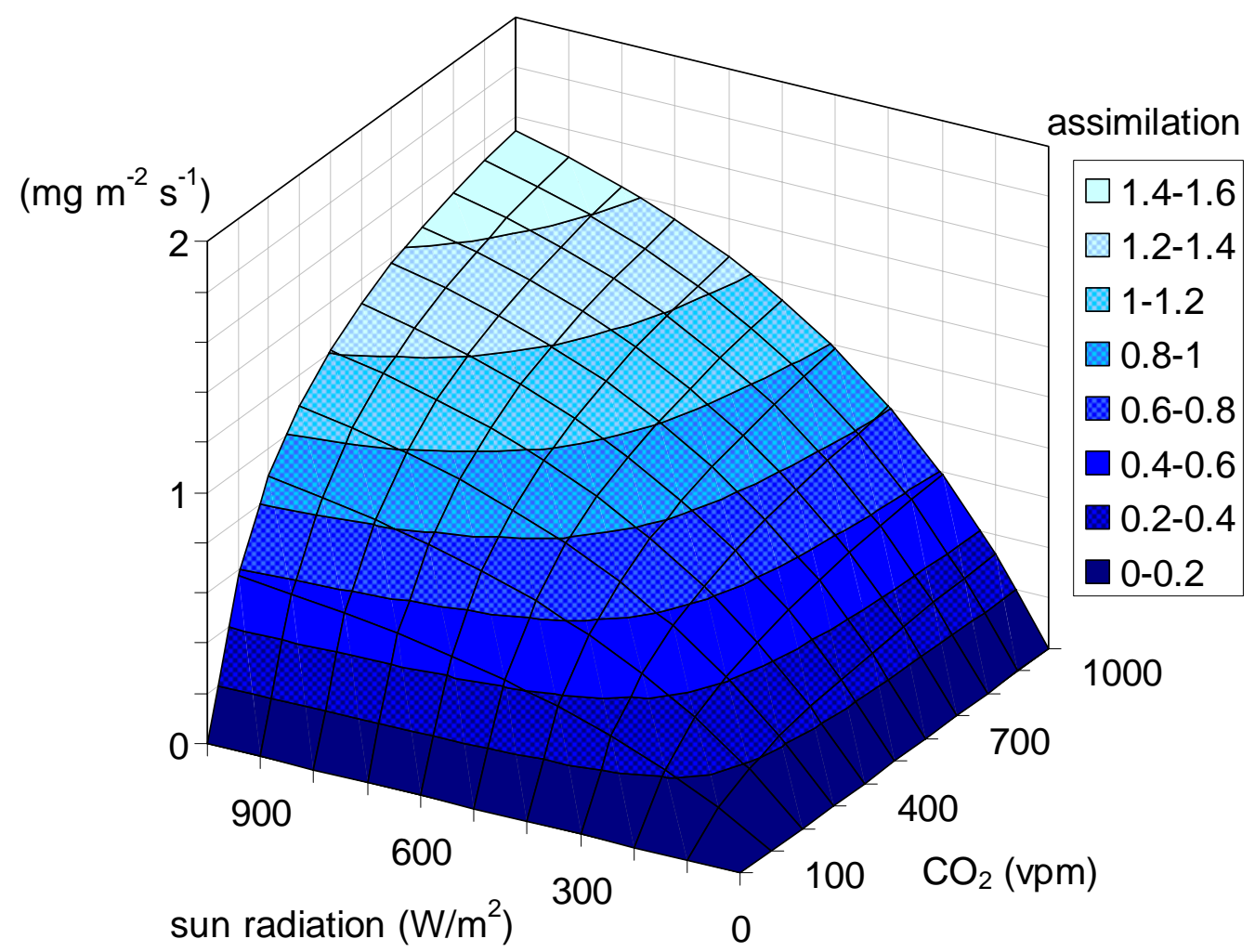

Figure 1. Response of net assimilation of a full-grown tomato crop to radiation and carbon dioxide concentration,as described by eq(1), a simplification of the model proposed by Nederhoff (1994).

In the semi-closed environment of a greenhouse without $\mathrm{CO}_{2}$ injection, the $\mathrm{CO}_{2}$ that is absorbed by the crop must be replaced by $\mathrm{CO}_{2}$ that comes from outside through the ventilation openings. The mass-flow continuity equation can be written as:

$$
A_{\text {net }}=g_{V}\left(C_{\mathrm{CO}_{2}}^{\text {out }}-C_{\mathrm{CO}_{2}}^{\text {in }}\right) \quad \mathrm{mg} \mathrm{m}^{-2} \mathrm{~s}^{-1}
$$

where $g_{V}$ is the volume exchange by ventilation, per unit surface area of the greenhouse, 
$\mathrm{m}^{3} \mathrm{~m}^{-2} \mathrm{~s}^{-1}$, that is: $\mathrm{m} \mathrm{s}^{-1}$, and $C$ is the $\mathrm{CO}_{2}$ concentration, $\mathrm{mg} \mathrm{m}^{-3}$, outside and inside respectively. Obviously, without additional sources of carbon dioxide, when there is assimilation, the concentration in the greenhouse must be lower than outside. This is shown by re-arranging eq(2):

$$
\mathrm{CO}_{2}^{\text {in }}=\mathrm{CO}_{2}^{\text {out }}-A_{\text {net }} / g_{V}
$$

If one prefers writing eq(3) in units more commonly used in greenhouse management, Avogadro's law gives the conversion from volume to mass: in the case of $\mathrm{CO}_{2}, 1 \mathrm{vpm} \cong 2$

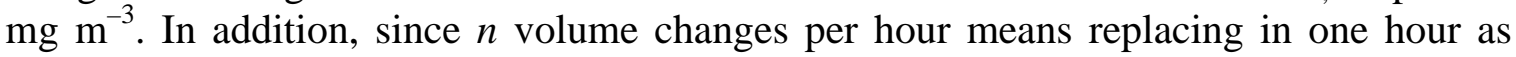
many cubic meters as the mean height, $h$, of the greenhouse $n=3600 g_{V} / h$. Thus:

$$
C O_{2}^{\text {in }}=C O_{2}^{\text {out }}-\frac{1800}{h} \frac{A_{\text {net }}}{n}
$$

For instance the $\mathrm{CO}_{2}$ concentration in a greenhouse of mean height $4 \mathrm{~m}$, ventilated at a rate of $4.5 \mathrm{~h}^{-1}$, with a crop assimilating $1 \mathrm{mg} \mathrm{m}^{-2} \mathrm{~s}^{-1}$ is some $100 \mathrm{vpm}$ lower than the concentration outside. With an external concentration of $370 \mathrm{vpm}$, this would mean some $20 \%$ of lost production, according to the "rule of thumb" that Nederhoff derived from her measurements. That rule reads as follows: the percentage increase of production caused by a $100 \mathrm{vpm}$ increase in concentration from a given mean $\mathrm{CO}_{2}$ level $(270 \mathrm{vpm}$, in this example) is:

$$
\text { production gain }=1.5\left(1000 / \mathrm{CO}_{2}\right)^{2}
$$

The $\mathrm{CO}_{2}$ fertilization strategy implemented in modern Dutch greenhouse climate computers is based on determining thus benefits of increasing the concentration, against the cost of $\mathrm{CO}_{2}$, either from gas fumes or bottled/piped from industrial plants.

\section{MATERIALS AND METHODS}

For finding out the extent of $\mathrm{CO}_{2}$ depletion in regions where $\mathrm{CO}_{2}$ fertilization is not common and discussing the options available to a mild-winter grower, we have used two existing data sets of November 2006, one from a 3-span multi-tunnel in the experimental station Las Palmerillas (El Eijdo, Almeria, Spain, 36 $48^{\prime} \mathrm{N} ; 2^{\circ} 43^{\prime} \mathrm{W} ; 151$ m.a.s.l.) and the other from a 14-span multi-tunnel of Azienda Fratelli Dezio, a commercial grower (loc. Gaspanella, Ragusa, Italy, 36 ${ }^{\circ} 7^{\prime} \mathrm{N} ; 1^{\circ} 26^{\prime} \mathrm{E}$; 104 m.a.s.l). The Spanish greenhouse are three spans, each 7.5 by $28 \mathrm{~m}$ (total surface $630 \mathrm{~m}^{2}$ ) oriented E$\mathrm{W}$, gutter height $3 \mathrm{~m}$ and $4.5 \mathrm{~m}$ on top, with side openings on the South and North facing sides, and a zenith opening in each module (Fig. 2, left). The commercial greenhouse in Italy is 14 modules 8 by $120 \mathrm{~m}$ each (total surface $1.34 \mathrm{ha}$ ), oriented SE-NW, gutter height $4 \mathrm{~m}$ and 5.6 on top. There are no side openings and one longitudinal on each tunnel (Fig. 2, right). In both cases the openings were fitted with insect nets type 20/10 and were controlled by the climate computer. In none of the two cases the heating system was switched on in the month of November.

The crop in Spain was a round Tomato, cv Colby, planted on August 4th, 2006 with a density of $2 \mathrm{~m}^{-2}$ whereas in Sicily it was a cherry, $c v$ Shiren, planted on September $18^{\text {th }}$, plant density $2 \mathrm{~m}^{-2}$. In both cases temperature, humidity and $\mathrm{CO}_{2}$ concentration within the greenhouse were recorded, together with standard outside conditions (sun radiation, temperature and humidity, velocity and direction of wind). Logging interval was $5 \mathrm{~min}$ in Almeria, 10 in Sicily. The Italian record is complete for the month of 

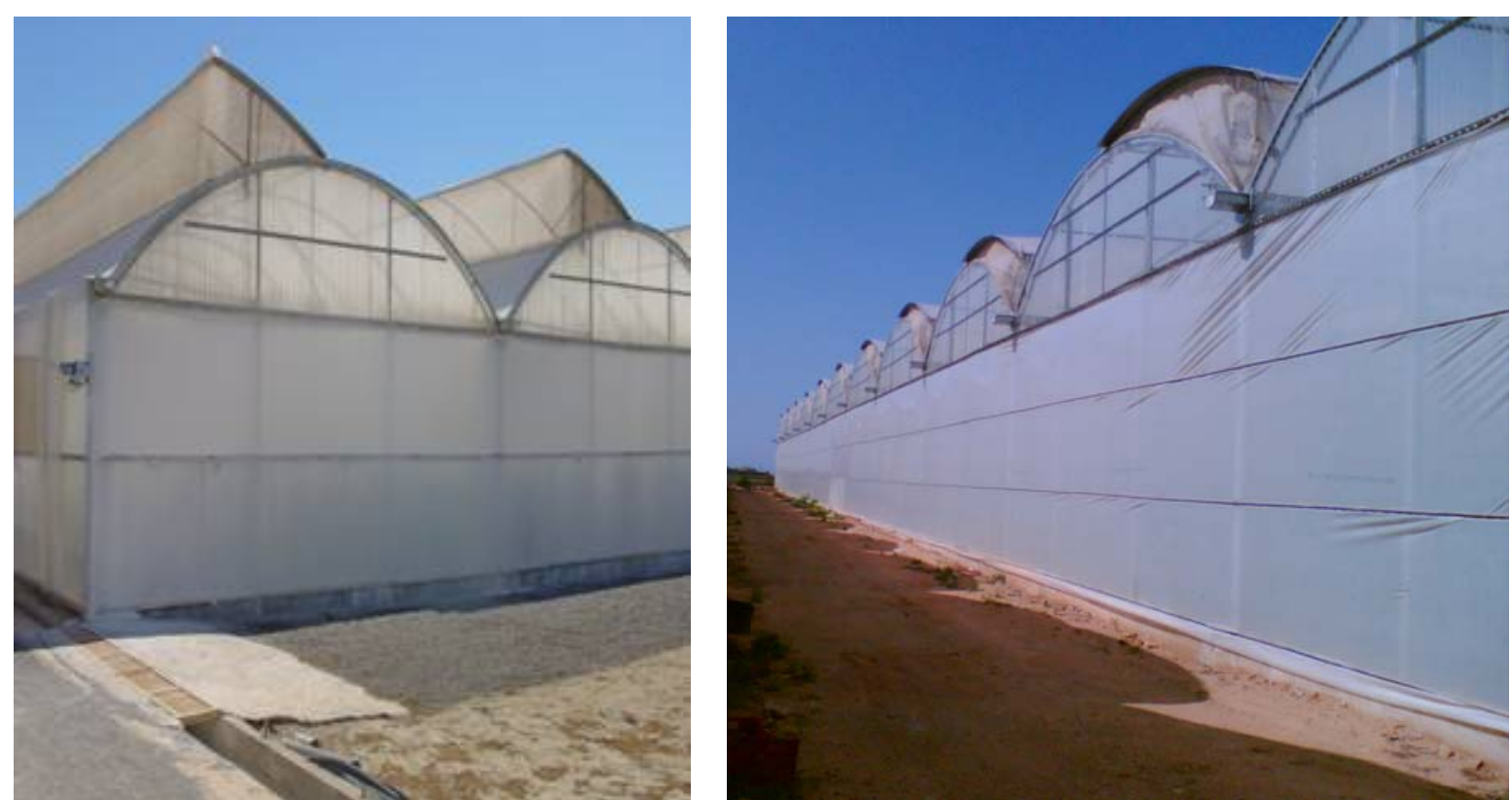

Figure 2. The greenhouses where the data used here were collected: left the Spanish greenhouse, right the one in Sicily, Italy.

November (chosen for its very similar weather conditions in the two places, Tab. 1) whereas the Spanish one is about 88\%. Unfortunately external concentration of $\mathrm{CO}_{2}$ wasn't measured in either place and only of the greenhouse in Sicily was the opening of the ventilators recorded.

As the mean measured $\mathrm{CO}_{2}$ concentration in a month that the Italian greenhouse was empty was $378 \mathrm{vpm}$, we have taken this value as the prevailing concentration outside, in both cases. Actual assimilation rate was estimated through eq(2), whereas a "potential" (that is, non limited by $\mathrm{CO}_{2}$ depletion) assimilation rate was estimated by using a constant value of $378 \mathrm{vpm}$ for $\mathrm{CO}_{2}$ concentration, for both locations. In order to "fill the gaps" in the Almeria record we preserved the ratio observed in the Ragusa record between totals for the days that were missing in Almeria and the month total.

\section{RESULTS}

Obviously this whole procedure can give only a very rough estimate of the total assimilation. It is a comforting thought that applying a dry matter allocation of 2/3 to the

Table 1. Average day- and night-time climate values measured out- and in-side the two greenhouses, in the month of November 2006, and estimated actual and potential assimilation (see text).

\begin{tabular}{lccccc}
\hline & & \multicolumn{2}{c}{ Daytime } & \multicolumn{2}{c}{ Night-time } \\
& & Almeria & Ragusa & Almeria & Ragusa \\
\hline Temperature out & ${ }^{\circ} \mathrm{C}$ & 19.4 & 18.2 & 15.3 & 13.0 \\
Total radiation & $M J \mathrm{~m}^{-2}$ & 255.80 & 250.96 & & \\
Wind velocity & $\mathrm{m} \mathrm{s}^{-1}$ & 1.6 & 2.0 & 0.8 & 0.9 \\
Temperature in & ${ }^{\circ} \mathrm{C}$ & 22.0 & 18.8 & 14.9 & 13.6 \\
$\mathrm{CO}_{2}$ in & $v \mathrm{vm}$ & 320.6 & 372.9 & 384.6 & 431.5 \\
\hline Estimated assimilation & $\mathrm{g} \mathrm{m}^{-2} \mathrm{month}^{-1}$ & 471.1 & 499.6 & & \\
Potential assimilation & $\mathrm{g} \mathrm{m}^{-2}$ month $^{-1}$ & 513.3 & 508.7 & & \\
\hline
\end{tabular}


fruits and a dry matter content of 6\%, the estimated tomato production in Almeria would be $5.06 \mathrm{~kg} \mathrm{~m}^{-2}$, which is comparable to the $4.95 \mathrm{~kg} \mathrm{~m}^{-2}$ that were harvested between Nov $3^{\text {rd }}$ and Dec $5^{\text {th }}$. The first harvest in the Sicilian farm was Dec $18^{\text {th }}$ and there are no records of vegetative growth.

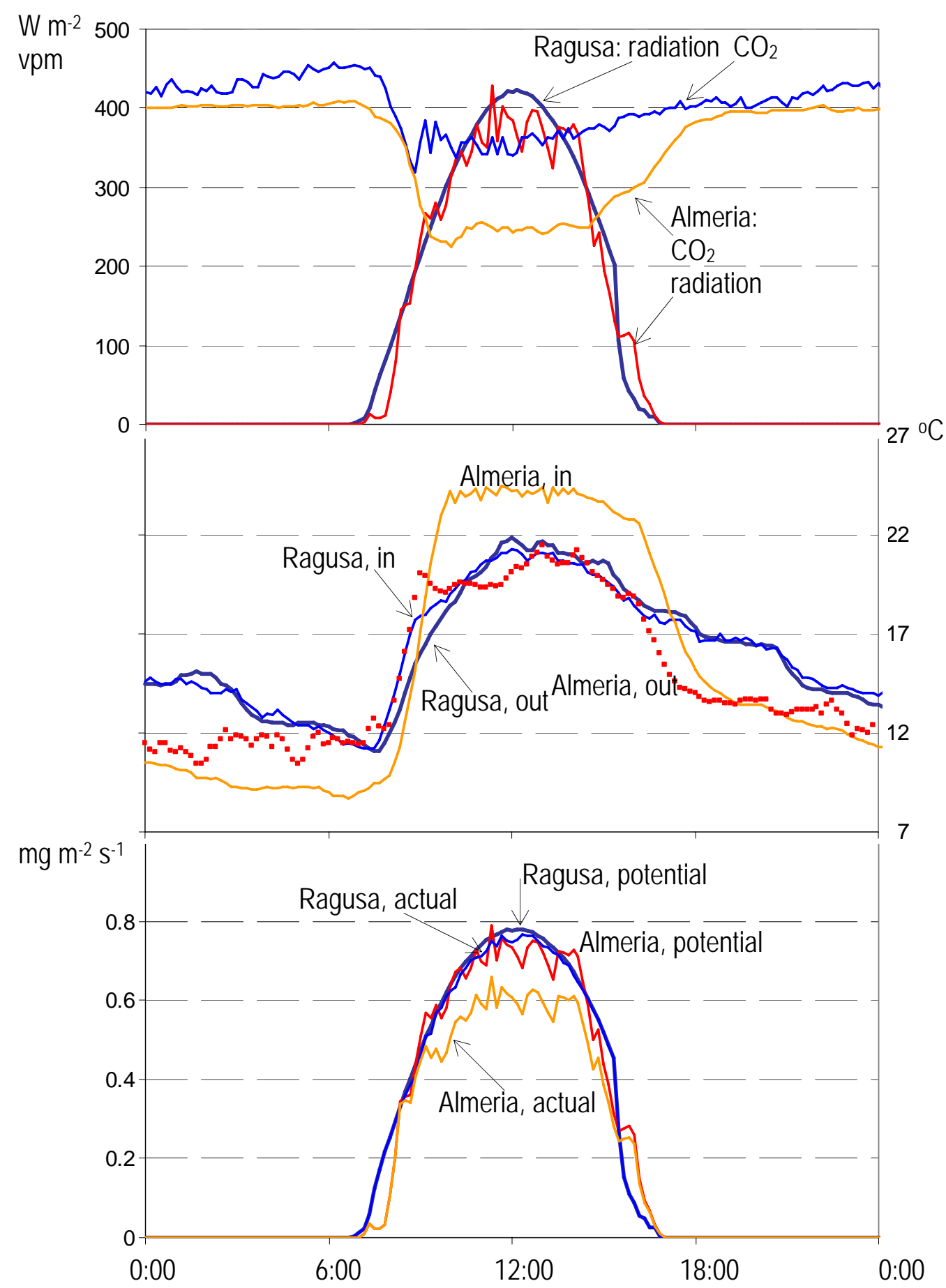

Figure 3. Measured radiation and $\mathrm{CO}_{2}$ concentration (top); in- and out-side temperatures (middle) at the two places on Nov $19^{\text {th }}$, 2006. The bottom panel shows the photosynthesis rate, eq(1). The "potential" rate is calculated with a fictive, constant $\mathrm{CO}_{2}$ concentration of $378 \mathrm{vpm}$. 
The differences in $\mathrm{CO}_{2}$ concentration and estimated assimilation, observed in Tab. 1 between the two places, are explained in Fig. 3, where a sunny day is shown as an example. Aside from the nights in this particular example-which were colder in Almeriathe weather in the two places was quite similar. Yet, whereas the temperature in the Italian greenhouse strictly shadowed outside temperature, the temperature in the Spanish house exceeded midday outside temperature by some $5^{\circ} \mathrm{C}$. This can only mean that the Italian house was much more ventilated than the Spanish one, which is consistent with the much higher daytime $\mathrm{CO}_{2}$ concentration.

\section{DISCUSSION}

In such conditions a grower is faced with a trade-off between ventilating in order to ensure sufficient inflow of carbon dioxide, and limiting ventilation to maintain a relatively high temperature. The two growers clearly adopted different strategies, which ensured very different climate conditions within the greenhouses, in spite of the similarity of the weather. According to the bottom panel of Fig. 3 a high ventilation rate was the better choice. Of course this is only half of the story, since our model, eq(1), does not reward higher temperatures.

Indeed it is known that photosynthesis of tomato is only slightly affected by temperatures in the range between 17 and $24^{\circ} \mathrm{C}$ (e.g. Heuvelink and Dorais, 2005), but all other growth-related process are. To begin with, re-distribution of assimilates is hampered by low temperatures. The ensuing accumulation in leaves limits their expansion, in young commercial tomato varieties (Heuvelink, 1989) as well as their wild relatives (Venema et al.,1999). Particularly in young plant this limits light interception, thus photosynthesis and thus crop growth. In addition, vegetative development (the differentiation of new leaves and trusses) is known to respond linearly to average temperature in a wide range. A much used "rule of thumb" for Dutch tomato growers is shown in Fig. 4. According to that, the grower in Almeria could harvest 3.8 trusses in the month November, whereas the one in Ragusa not even 3.4. Obviously this is quite speculative, since the two growers did not even have the same variety. De Koning (1994), however, observed that, although the slope could change across varieties, the response of truss formation to temperature

trusses per week

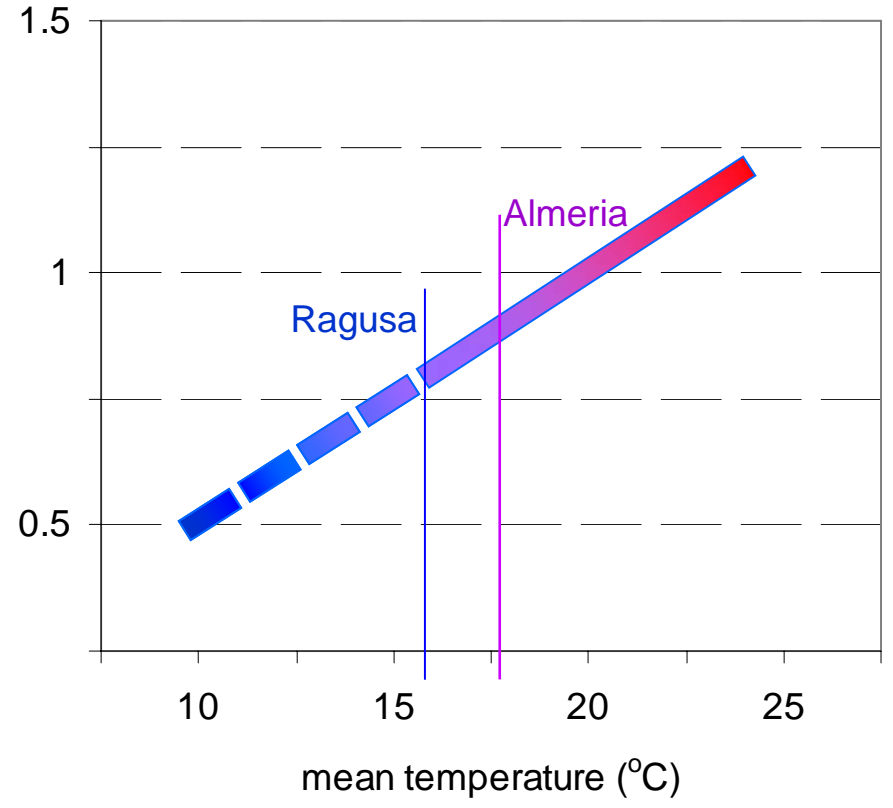

Figure 4. Effect of the average greenhouse temperature on the number of trusses formed per week in tomato, experimentally determined by De Koning (1994) on commercial round varieties. De Koning's measurements were limited to the range 16 to $24^{\circ} \mathrm{C}$ and the dashed line is an extrapolation for the sake of this discussion. 
remained linear. Altogether, the $8 \%$ production loss (Tab. 1) caused by $\mathrm{CO}_{2}$ depletion in Almeria, was comparable to the production loss due to the lower temperature caused by ventilation in the Ragusa farm. Obviously, the fact that the monthly mean outside temperature was about $1.5^{\circ} \mathrm{C}$ lower in Ragusa would have required an even lower ventilation rate (and larger depletions) to achieve the mean temperature that was measured in Almeria. On the face of it, both growers may have selected the best course in their conditions.

The significance of a production loss of some $8 \%$ is brought home if one considers, for instance, that the margin of Dutch tomato producers is some $10 \%$. Mediterranean growers usually have higher margins and higher risks, Stanghellini (2005). Sub-optimal production, however, is fast becoming something that no grower can afford, in a global market that only rewards dependable, steady deliveries of consistently high quality. In these conditions, then, a grower has to choose the lesser of two evils: heating or carbon fertilization. According to the response shown in Fig. 4 an average temperature $1^{\circ} \mathrm{C}$ higher implies $5 \%$ more trusses. So the $8 \%$ production loss caused by depletion in Almeria could have been compensated by a mean temperature $1.6^{\circ} \mathrm{C}$ higher. The heating energy this would have required can be estimated from the model developed by Lopez et al (2006) on the basis of several experiments in Almeria. They found out that the daily amount of energy $Q_{d}$ required to maintain a $\Delta T_{\min }$ difference between the heating set-point and the daily minimum temperature $T_{\min }$, is well described by the quadratic expression:

$$
Q_{d}=0.0497 \Delta T_{\min }^{2}-0.001 \Delta T_{\min }+1.107
$$$$
M J m^{-2} d^{-1}(6)
$$

Calculating eq(6) with a daily $\Delta T_{\min } 1.6^{\circ} \mathrm{C}$ degrees higher than it was actually observed, results in an additional energy requirement of some $23.5 \mathrm{MJ} \mathrm{m}^{-2}$, that is $0.52 \mathrm{~kg}$ propane gas per square meter. Current prices of piped propane in Spain is about $0.76 € / \mathrm{kg}$ (Repsol YPF, 2007), so that the cost of increasing month production by $8 \%$ (some $0.5 \mathrm{~kg} \mathrm{~m}^{-2}$ ) by heating would have been $0.32 € / \mathrm{m}^{-2}$. Obviously, a "smarter" heating strategy than just increasing the mean of each day by $1.6^{\circ} \mathrm{C}$, would have lowered somehow the energy requirement. Nevertheless, as the Spanish producer price of tomato in November the year before seldom had exceeded $0.60 € / \mathrm{kg}$ (Fundación Cajamar, 2006), it is doubtful that a grower would find this a sensible investment, since the (sure) costs are comparable to the (probable) benefits-although the chance to use the fumes for carbon enrichment could improve the balance.

Another option would be to compensate for depletion through carbon dioxide fertilization. If one were able to maintain the concentration within the greenhouse at the outside level, there would be no transfer of $\mathrm{CO}_{2}$ either way, and all the $\mathrm{CO}_{2}$ one would need to inject in the greenhouse would be the $\mathrm{CO}_{2}$ assimilated by the crop. However, one has to take into account the conversion efficiency of $\mathrm{CO}_{2}$ fixation into dry matter (about 0.7 ) and the ratio of molecular weights of $\mathrm{CH}_{2} \mathrm{O}$ and $\mathrm{CO}_{2}$ (another factor around 0.7), which means that each kg dry matter assimilated needs $2 \mathrm{~kg}$ of $\mathrm{CO}_{2}$ for photosynthesis (Stanghellini and Heuvelink, 2007). In the absence of losses through ventilation the difference between the actual and "potential assimilation" of Tab. 1 (calculated by assuming a $\mathrm{CO}_{2}$ concentration of $378 \mathrm{vpm}$, the estimated outside concentration) allows us to gauge the $\mathrm{CO}_{2}$ requirement, that would have been about $100 \mathrm{~g} \mathrm{~m}^{-2}$ for the month of November 2006. Considering that current world prices of bottled or piped $\mathrm{CO}_{2}$ are between 0.1 and $0.2 € / \mathrm{kg}$ (and going down, thanks to the Kyoto treaty) that would have been certainly worthwhile-if a grower had the installation for carbon fertilization. 


\section{CONCLUSION}

Each of the two choices available to low-tech grower in a mild-winter region: ventilate as much as possible to avoid depletion; or keeping a high temperature in spite of depletion results in some $10 \%$ lost production. The roughness of this analysis does not allow indicating the best strategy for sure. However, what is sure is that running costs of increasing production through $\mathrm{CO}_{2}$ fertilization are much cheaper by far than heating to increase production by a similar amount. Though we refrained from a financial analysis, it is quite likely that most growers could expect a good return on the investment of an installation for $\mathrm{CO}_{2}$ fertilization.

If such an installation were available, a good management strategy would be to ventilate as little as possible (that is, as little as the control of humidity would allow) and control the $\mathrm{CO}_{2}$ concentration within the house up to the level outside, in presence of ventilation, and to a much higher level (1000 vpm is common for Dutch tomatoes) when no ventilation is required.

\section{Acknowledgments}

Our most sincere appreciation is for the owners of Azienda Fratelli Dezio, one of the leading tomato producers in Sicily, who very kindly made available their full data record and timely answered all our remaining questions; and to Frank Kempkes who found the time to read and comment-keenly, as usual-this paper.

\section{References}

De Koning, A.N.M. 1994. Development and dry matter distribution in glasshouse tomato: a quantitative approach. PhD dissertation Wageningen Agricultural University, Wageningen, $240 \mathrm{pp}$.

Fundación Cajamar, 2006. Análisis de la campaña hortofrutícola de Almería: Campaña 2005/2006. Fundación Cajamar, Almeria, 38 pp.

Heuvelink, E. 1989. Influence of day and night temperature on the growth of young tomato plants. Scientia Horticulturae, 38: 11-22.

Heuvelink, E. \& Dorais, M. 2005. Crop growth and yield. In: Heuvelink E. (Ed.) Tomatoes. CABI publishing, Wallingford, ISBN 085199 3966: 85-144.

López, J.C., Baille, A., Bonachela, S., González-Real, M.M. \& Pérez-Parra, J. 2006. Predicting the energy consumption of heated plastic greenhouses in south-eastern Spain. Spanish Journal of Agricultural Research, 4(4): 289-296.

Nederhoff, E.M. 1994. Effects of $\mathrm{CO}_{2}$ concentration on photosynthesis, transpiration and production of greenhouse fruit vegetable crops. $\mathrm{PhD}$ dissertation, Agricultural University, Wageningen, 213 pp.

Repsol YPF, 2007. http://www.repsolypf.com/es_es/productos_y_servicios/productos/ glp_butano_y_propano/paises/espana/gas_propano_canalizado/informacion_come rcial/como_ser_cliente/precios/default.aspx

Stanghellini, C. 2005. La serra, mediatrice fra coltura e clima. In: Strategie per il miglioramento dell'orticoltura protetta in Sicilia, U.O.S. 83, Comiso (RG), Italy: 29-38.

Stanghellini, C. \& Heuvelink, E. 2007. Coltura e clima: effetto microclimatico dell'ambiente serra. Italus Hortus, 14(1): 37 - 49.

Venema, J.H., Posthumus, F. \& Van Hasselt P.R. 1999. Impact of suboptimal temperature on growth, photosynthesis, leaf pigments and carbohydrates of domestic and highaltitude wild Lycopersicon species. Journal of Plant Physiology, 155: 711-718. 